\title{
Study of the effect of Kaolin in the mortar of cement matrices by confinement of ion exchange resins
}

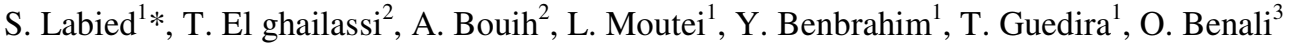

${ }^{1}$ Laboratory of Materials Electrochemistry and Environment, Faculty of Science, University Ibn Tofail, BP 133, 14000 Kenitra, Morocco

${ }^{2}$ Unit of Management of radioactive waste, National Center of Nuclear Energy, Sciences and Nuclear Techniques (CNESTN), Center for Nuclear Studies of Maamoura (CENM).PB 1382, 10001 Kenitra, Morocco

${ }^{3}$ Laboratory of Separation Processes, Faculty of Science, University Ibn Tofail, BP 133, 14000 Kenitra, Morocco

*Corresponding author: E-mail: labiedsoumiya@gmail.com; Phone :(212) 601706599

\begin{abstract}
Radioactive waste arising as a result of nuclear activities should be safely managed from its generation to final disposal in an appropriate conditioned form to reduce the risk of radiation exposure of technical personnel and of the public and to limit contamination of the environment. The immobilization of low and intermediate level radioactive wastes in cementitious matrices is the most commonly used technique to produce inexpensive waste matrix that complies with regulatory requirements in order to protect humans and the environment against nuisance caused by ionizing radiation. Cement based materials are used in radioactive waste management to produce stable waste forms. This matrix constitutes the first build engineering barrier in disposal facilities. In this work, the kaolin is used to enhance the mechanical performance of the matrix of confinement of ion exchange resins by gradually replacing the sand in mortar with kaolin clay. The Kaolin clay sample was a special pure product, sourced from a foreign country. The maximum quantity of resins that can be incorporated into the mortar formulation without the packages losing their strength is $13.915 \%$ which results in a better mechanical strength at 6.7686 MPA compression with kaolin.
\end{abstract}

\section{INTRODUCTION}

The use of nuclear techniques in various fields such as scientific research, industry and health generates radioactive waste. This waste is composed of different types. Like any developing country, Morocco is responsible for the management of radioactive waste through the National Center for Energy, Science and Nuclear Techniques (CNESTEN). CNESTEN has set up a Radioactive Waste Management Unit (RWMU). This management must be carried out within a rigorous framework in order to guarantee safe solutions for all radioactive waste produced without losing sight of the 
permanent requirement for the protection of present and future generations and the risk environment of this waste [1-2].

The low- and intermediate-level radioactive waste conditioning process at the UGDR is immobilization in a cement-based matrix, which is the first barrier of this waste, is the most common technique used to produce radioactive waste packages that comply with regulatory requirements [3-4-5].

As a result of extensive research activities focused on the development of materials, the additives are currently among the most recent developments in cement production, as their uses improve the mechanical properties of cementitious materials (mortar and concrete). Indeed, the incorporation of kaolinite into the mortar obviously produces materials similar to ordinary cement mortar but with best characteristics [6-8].

The aim of this study is to optimize the formulation of a cement matrix by gradually substituting the proportion of sand by kaolinite as a filler. We then follow the impact of this substitution on the compressibility of the test pieces while keeping the $\mathrm{E} / \mathrm{C}$ ratio constant.

\section{MATERIALS AND METHODS}

\subsection{Materials}

\subsubsection{Cement}

The portland cement used CPJ 35 is a cement whose technical characteristics are in conformity with the Moroccan standard NM 10.1.004.

\subsubsection{Sand}

The sand used in a laboratory complies with the Moroccan standard NM 10.1.020. We also use this sand for industrial applications for the confinement of radioactive waste.

\subsubsection{Water}

We used drinking tap water to make mortars

\subsubsection{Ion exchange resins}

The ion exchange resins $[9,10]$ MDP-15 type, in of clear spherical beads form used in the purification of the reactor water circuits as well as the spent fuel storage pools of the TRIGA MARK II reactor, PUROLITE NRW 37 type, these cations exchange resins are strongly acid, and gel type.

The ion exchange is a process by which the ions contained in a solution are removed to be replaced by an equivalent number of other ions of the same electrical charge. The physical-chemical properties of the resin:

- Hydrocarbon skeleton: Polystyrenic crossed to the gel type DVB

- Functional grouping: R-SO3-

- Physical form: Dark amber balls, translucent

- Ion Shape at delivery: H-
- Moisture content: 51-55\% ( $\mathrm{H}+$ form $)$

- Maximum swelling: $\mathrm{Na}+-\mathrm{H}+: 5 \%$

- Temperature limit: $120{ }^{\circ} \mathrm{C}$

- Limit of PH: From 0 to 14

- Apparent density: Approximately $800 \mathrm{~g} / 1$

- Actual Density: 1.20 (H + Form)

- Total exchange capacity: Min 1.7 eq / 1 ( $\mathrm{H}+$ form $)$

\subsection{Experimental section}

The different pastes are prepared in a standardized mixer EN-196-1 [11] following the procedure indicated in standard EN-196-3 [12] relating to the normal consistency of pure pasta.

\subsubsection{Study of the influence of the substitution of sand by kaolinite on the mortar}

For our experimental approach, four types of mortars were prepared with substitution percentages ranging from 0 to $6 \%$ of the kaolinite. The tests were carried out using $10 \times 5.5 \mathrm{~cm}$ cylindrical specimens, the walls of which were previously washed with oil (Sika type Iron M) which is a demolding agent. the demolding takes place after the following periods: 7 days, 14 days, 21 days and 28 days. The various compositions of the mortars are grouped in Table 1.

Table 1 : Formulation tests

\begin{tabular}{|l|l|l|l|l|l|}
\hline & \%/weight (g) & Cement & Sand & Kaolinite & Water \\
\hline \multirow{2}{*}{ witness } & $\%$ & 57.14 & 20 & 0 & 22.85 \\
\cline { 2 - 6 } & weight (g) & 1828.57 & 640 & 0 & 731.43 \\
\hline \multirow{2}{*}{ Test 1 } & $\%$ & 57.14 & 18 & 2 & 22.85 \\
\cline { 2 - 6 } & weight (g) & 1828.57 & 576 & 64 & 731.43 \\
\hline \multirow{2}{*}{ Test 2 } & $\%$ & 57.14 & 16 & 4 & 22.85 \\
\cline { 2 - 6 } & weight (g) & 1828.57 & 512 & 128 & 731.43 \\
\hline \multirow{2}{*}{ Test 3 } & $\%$ & 57.14 & 14 & 6 & 22.85 \\
\cline { 2 - 6 } & weight (g) & 1828.57 & 448 & 192 & 731.43 \\
\hline
\end{tabular}

\section{RESULTS AND DISCUSSION}

\subsection{Result of particle size analysis of kaolinite}

Figure 1 presents the granulometric analysis of kaolinite which is carried out by series of sieves $(88 \mu \mathrm{m}, 74 \mu \mathrm{m}, 62$ $\mu \mathrm{m}, 37 \mu \mathrm{m})$. 


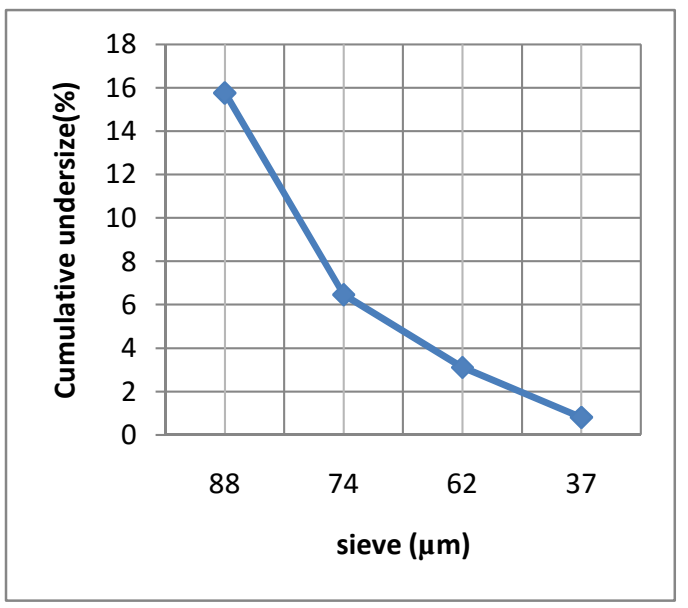

Fig. 1. Grading curve of the kaolinite

\subsection{Quantitative chemical analysis of the used materials.}

The chemical composition of the samples was determined by The Portable Fluorescence X System with Dispersion of Energy (Bruker S1 Turbo SD). The results obtained are expressed in mass percent.

Table 2. X-Fluorescence Analysis Results

\begin{tabular}{|c|c|c|c|c|c|c|c|}
\hline & \multicolumn{7}{|c|}{ Chemical components (\%) } \\
\cline { 2 - 7 } & $\mathrm{Al}_{2} \mathrm{O}_{3}$ & $\mathrm{SiO}_{2}$ & $\mathrm{P}_{2} \mathrm{O}_{5}$ & $\mathrm{~K}_{2} \mathrm{O}$ & $\mathrm{CaO}$ & $\mathrm{TiO}_{2}$ & $\mathrm{Fe}_{2} \mathrm{O}_{3}$ \\
\hline Kaolinite & $\begin{array}{c}40.97 \\
\pm 0.65\end{array}$ & $\begin{array}{c}55.59 \\
\pm 0.50\end{array}$ & $\begin{array}{c}0.78 \\
\pm 0.04\end{array}$ & $\begin{array}{c}1.34 \\
\pm 0.02\end{array}$ & $\begin{array}{c}0.05 \\
\pm 0.01\end{array}$ & $\begin{array}{c}0.22 \\
\pm 0.01\end{array}$ & $\begin{array}{c}1.03 \\
\pm 0.01\end{array}$ \\
\hline
\end{tabular}

\subsection{XRD analysis of used materials}

Figure 2 shows X Ray diffractogram of kaolinite.

Fig. 2. X-Ray Diffractogram of Kaolinite

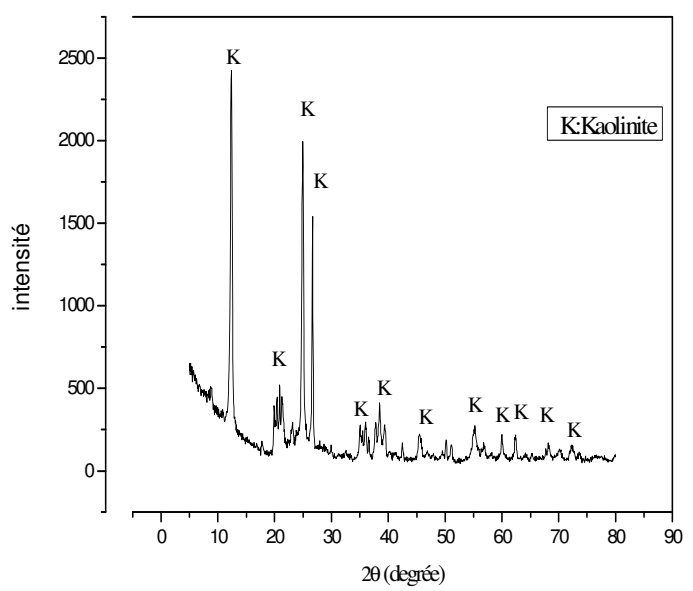

\subsection{Formulation tests}

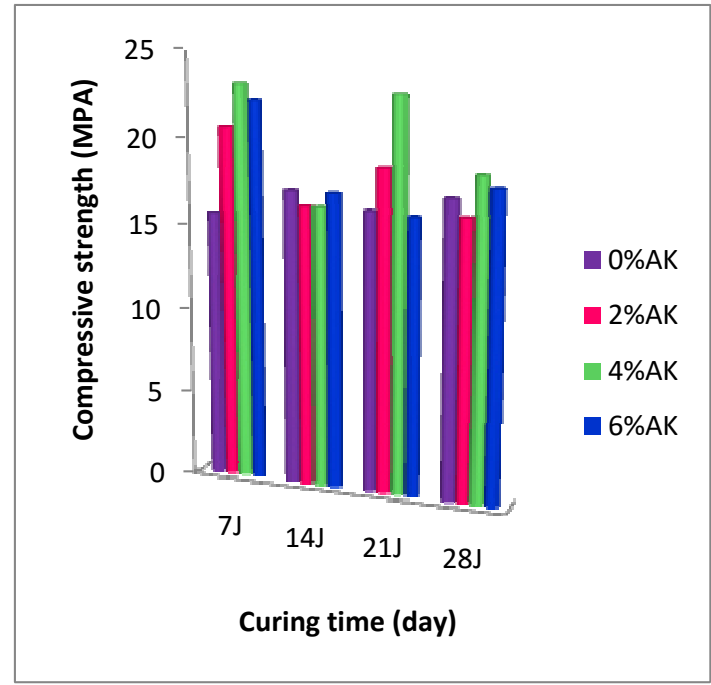

Figure 3. Evolution of the mechanical strength as a function of the curing time of the matrices prepared with different amounts of kaolinite.

The evolution of the resistances as a function of time shows that for seven days as curing time, the resistance corresponding to all the percentages of kaolinite inserted exceeds that of the control mortar.

The evolution of the resistances as a function of time shows that after 28 days the resistance corresponding to $2 \%$ kaolinite does not exceed that of the control mortar, while for those of $4 \%$ and $6 \%$ the resistances increase substantially. Due to the kinetics of the hydration reaction of the constituents of the mixed cement which becomes more and more active.

The evolution of the resistances as a function of time shows that for a cure time of 28 days, the best resistance corresponds to the incorporation of $4 \%$ of kaolinite in the mortar.

This improvement can be explained by the double role of kaolinite [13-14-15]:

It permits to fill the tiny voids in the mortar due to its very high fineness.

And there is the pozzolanic effect, the silica It will combine with the portlandite resulting from the hydration of the reactive phases of the clinker to form CSH [16-17].

\subsection{Confinement of resins formulation}

After finding that optimal formulation corresponds to substitution of $4 \%$ of the kaolinite instead the sand, we incorporate a radioactive waste in the matrix in percentages ranging from $3.479 \%$ to $13.915 \%$ in order to determine the maximum rate of this waste that we can confined in the matrix (Table 3 ). 
Table 3.confinement of resins formulation

\begin{tabular}{|l|l|l|l|l|l|l|}
\hline & $\begin{array}{c}\text { \%/weight } \\
\text { (g) }\end{array}$ & $\begin{array}{c}\text { Cem } \\
\text { ent }\end{array}$ & Sand & $\begin{array}{l}\text { kaolinit } \\
\text { e }\end{array}$ & Water & \multicolumn{1}{|c|}{$\begin{array}{c}\text { Wet } \\
\text { resin }\end{array}$} \\
\hline \multirow{2}{*}{ Test 7 } & $\%$ & 57.14 & 16 & 4 & 22.85 & 0 \\
\cline { 2 - 7 } & weight(g) & $\begin{array}{l}1828 . \\
57\end{array}$ & 384 & 128 & 731.43 & 0 \\
\hline \multirow{2}{*}{ Test 8 } & $\%$ & 56 & 15.6 & 4 & 20.921 & 3.479 \\
\cline { 2 - 7 } & weight(g) & 1792 & 499.2 & 128 & 669.472 & 111.328 \\
\hline \multirow{2}{*}{ Test 9 } & $\%$ & 54.86 & 15.2 & 4 & 18.982 & 6.958 \\
\cline { 2 - 7 } & weight(g) & $\begin{array}{l}1755 . \\
52\end{array}$ & 486.4 & 128 & 607.424 & 222.656 \\
\hline \multirow{2}{*}{ Test 10 } & $\%$ & 53.71 & 14.8 & 4 & 17.044 & 10.436 \\
\cline { 2 - 7 } & weight $(\mathrm{g})$ & 1718. & 473.6 & 128 & 545.408 & 333.952 \\
\hline \multirow{2}{*}{ Test 11 } & $\%$ & 52.57 & 14.4 & 4 & 15.153 & 13.915 \\
\cline { 2 - 7 } & weight $(\mathrm{g})$ & 1682. & 460.8 & 128 & 484.896 & 445.28 \\
\hline
\end{tabular}

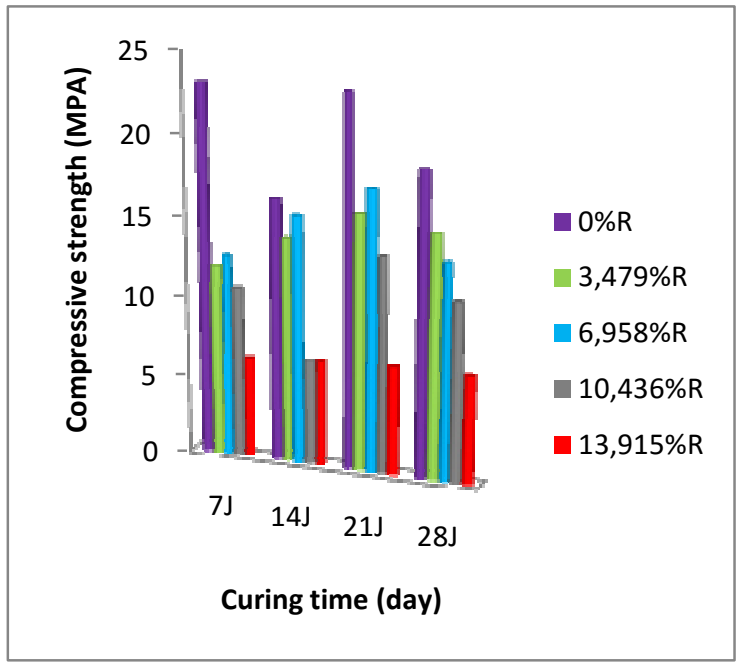

Figure 4 variations of compressive strength for different percentages of resins (R) incorporated in a mortar, according to the age of the test pieces

We observe a decrease in the compressive strength with the increase of the quantity of the ion exchange resins incorporated in the mortar. The maximum quantity of resins which can be incorporated in this formulation without the packages losing their resistances is $13.915 \%$. Indeed, the compressive strength for this formulation is 6.7686 MPA and seems the most suitable for the conditioning of the resins.

\section{Conclusions}

The compressive strengths increase with the substitution of sand by kaolinite, thus reflecting the improvement of compactness by three effects which act simultaneously and in a complementary manner: physical, physicalchemical and chemical (pozzolanic) effect.

the main result is that the maximum amount of ion exchange resin that can be incorporated into the cement matrix is $13.95 \%$. This precntage corresponds to a compressive strength of $6.7686 \mathrm{MPa}$. The package keeps a good resistance.

\section{REFERENCES}

1. Collection normes de sureté de l'AIEA, Gestion des déchets radioactifs avant stockage définitifs y compris le déclassement AIEA n ${ }^{\circ}$ WS-R-2 VIENNE 2004.

2. T. El Ghailassi «Système de gestion des déchets radioactifs entreposage des déchets radioactifs et combustible Usé Triga Mark II » Rapport de titularisation (2008).

3. Céline PERLOT, «Influence de la décalcification de matériaux cimentaires sur les propriétés de transfert: Application au stockage profond de déchets radioactifs» Thèse de doctorat, Université Paul Sabatier de Toulouse U.F.R. P.C.A.( 23 Septembre 2005).

4. Junfeng Li, Jianlong Wang, J Hazard Mater, B135 (2006) 443-448.

5. A.Erdal Osmanlioglu Waste Management, Volume 22, Issue 5, August 2002, Pages 481-483.

6.Zheng Guo, Qiming Feng, Weiqing Wang, Yang Huang, Jie Deng, Zhonghui Xu, Procedia Environmental Sciences 31 ( 2016 ) $644-652$.

7.El Ghailassi T., Aoulad Belayachi, A. Bouih, S. Labied, T. Guedira, O. Benali. Mathematical approach for research of new formulation for immobilization of radioactive waste in cementitious matrices, J. Mater. Environ. Sci. (JMES), 8 (11), 3864-3872 (2017)

8. Yingfang Fan, Shiyi Zhang, Qi Wang, Surendra P. Shah, Construction and Building Materials 102 (2016) 486-495.

9. Faiz Z., Fakhi S., Bouih A., Idrissi A., Mouldouira M., J. Mater. Environ. Sci. 3 (6) (2012) 1129-1136.

10. Elhilal B., Lambarki El Allioui T., Bouih A., El Harfi A.,"Characterization of ion exchange resinsused in the purification of nuclearreactor water circuits TRIGA MARK II" article soumis au Journal of Materials and Environmental Science (JMES).

11. International atomicenergyagency, Vienna, Technical Reports Series No. 408: Applications of ions exchange processes for de treatment of radioactive waste and management of spent ion exchanges (2002).

12. «Méthodes d'essais des ciments, partie 3: Détermination du temps de prise et de la stabilité», Août (1995).

13.Geetika Mishra, Anuj Parashar, Shashank Bishnoi, ICSBE2016-100.

14. Abraham Teklay, Chungen Yin, Lasse Rosendahl, Department of Energy Technology, Aalborg University, 9220 Aalborg East, Denmark, Applied Energy (2015)

15. A. Elimbi, H.K. Tchakoute, D. Njopwouo, Construction and Building Materials 25 (2011) 28052812.

16. Chahidi ElouazzaniD.,Caractérisation physicochimique et valorisation en bâtiment et travaux publics des cendres issues de l'incinération des boues de papeterie, thèse de Doctorat , Institut national des sciences appliquées de Lyon, 2005, P 18-21.

17. Z.Faiz ; S. Fakhi ; A. Bouih ; A. Idrissi ; M. Mouldouira J. Mater. Environ. Sci. 3 (6) (2012) 11291136 . 